\title{
Effect of different surface finishing/polishing procedures on color stability of esthetic restorative materials: A spectrophotometric evaluation
}

\author{
Riccardo Beltrami ${ }^{1}$, Matteo Ceci ${ }^{1}$, Gabriele De Pani ${ }^{1}$, Lodovico Vialba ${ }^{1}$, \\ Ricaldone Federico ${ }^{1}$, Claudio Poggio ${ }^{1}$, Marco Colombo ${ }^{1}$
}

Correspondence: Dr. Claudio Poggio

Email: claudio.poggio@unipv.it
'Department of Clinical-Surgical, Diagnostic and Pediatric Sciences, Section of Dentistry, University of Pavia, Pavia, Italy

\section{ABSTRACT}

Objective: To evaluate the color stability of different esthetic restorative materials after surface finishing/polishing with different procedures. Materials and Methods: All materials were polymerized into silicone rubber rings to obtain specimens identical in size. Samples were randomly assigned into four groups (10 specimens of each composite for each group), and they were finished with different procedures: Control group (Group 1), three or two polishers interspersed with diamond grit (Groups 3 and 2 , respectively), and one tungsten carbide bur + one polisher interspersed with diamond grit (Group 4). After staining process in coffee, a colorimetric evaluation according to the CIE L*a*b* system was performed by a blind trained operator at 7, 14, 21, and 28 days. Shapiro-Wilk test and Kruskal-Wallis analysis of variance were applied to assess significant differences among restorative materials. Means of the different polishing/finishing groups were compared with Scheffe's multiple comparison test at the 0.05 level of significance. Results: In control group, significant lower discolorations were recorded for Essentia, Admira Fusion, and Estelite. After finishing, Filtek Supreme XTE and Ceram.X Universal showed a significantly lower degree of staining. The finishing technique used for Group 4 produced higher color changes. Conclusions: Tungsten carbide burs produced the higher color variations; after finishing, the nanofilled composites showed lower discoloration than nanohybrid ones, and the time of exposure to the staining agent and the polishing/finishing technique influenced the color change.

Key words: CIE L*a*b*, color stability, esthetic restorative materials, finishing, polishing

\section{INTRODUCTION}

The quality of esthetic restorations greatly depends on the accuracy of finishing and polishing techniques used. ${ }^{[1]}$ Finishing and polishing procedures which refer to gross contouring of the restoration to obtain the desired anatomy, to reduce the roughness and scratches, are essential to periodontal and marginal integrity and wear reduction. ${ }^{[2]}$ Polished surfaces minimize the plaque accumulation, gingival irritation, poor esthetics, surface discoloration, and secondary

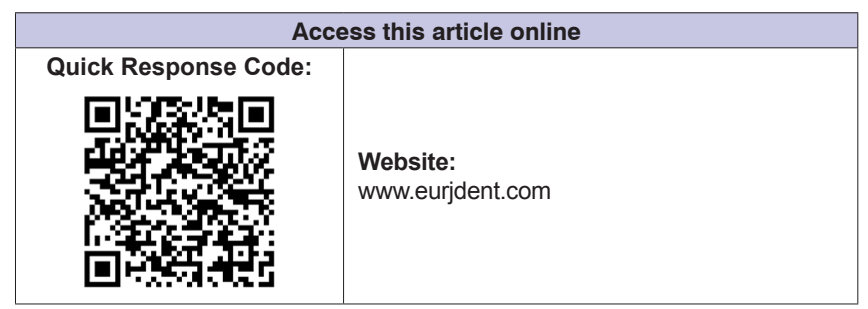

caries. ${ }^{[3]}$ A smooth surface is clinically important as it determines the esthetics and longevity of the composite resin restorations. ${ }^{[4]}$ Surface roughness seems to affect the initial adhesion of cells; moreover, gingival health is subjected to surface texture of the restoration. ${ }^{[5]}$

Various techniques for polishing and finishing have been investigated: aluminum oxide disks, fine

This is an open access article distributed under the terms of the Creative Commons Attribution-NonCommercial-ShareAlike 3.0 License, which allows others to remix, tweak, and build upon the work non-commercially, as long as the author is credited and the new creations are licensed under the identical terms.

For reprints contact: reprints@medknow.com

How to cite this article: Beltrami R, Ceci M, De Pani G, Vialba L, Federico R, Poggio C, et al. Effect of different surface finishing/polishing procedures on discoloration of esthetic restorative materials: A spectrophotometric evaluation. Eur J Dent 2018;12:49-56.

DOI: 10.4103/ejd.ejd_185_17 
diamond burs, carbide burs, resin points, and polishers with diamond grit. ${ }^{[6]}$ Several studies suggested that certain polishing techniques may be suited to specific materials. ${ }^{[7]}$ However, it was stated that it is difficult to achieve a highly polished surface of composite resin restorations; resin matrix and filler particles do not abrade to the same degree due to different hardness: Craters are often formed around hard quartz particles of conventional composites so that irregularities appear on the surface of the restoration. ${ }^{[8]}$

Discoloration represents a significant problem for direct tooth-colored restorations, with various studies reporting the overtime color change of composite resins due to extrinsic or intrinsic factors. ${ }^{[9]}$ Changes in color depend on several factors, such as staining agent, composite resin, and smoothness of the polished surface ${ }^{[10]}$ Optical properties and color stability were in fact influenced by surface changes during restorative procedures of finishing and polishing. ${ }^{[5]}$ Discoloration can be assessed visually and using instrumental techniques. Instrumental techniques eliminate the subjective interpretation inherent in a visual color comparison. Therefore, spectrophotometers and colorimeters are widely used tools to detect the color changes in dental restorative materials. ${ }^{[11]}$ Color change $(\Delta \mathrm{E})$ mathematically expresses the amount of difference between the $\mathrm{L}^{*} \mathrm{a}{ }^{*} \mathrm{~b}^{*}$ coordinates of different specimens or the same specimen at different instances. ${ }^{[12]}$

The aim of this in vitro study was to evaluate and compare the color stability of various esthetic restorative materials after surface finishing/polishing with different procedures. The null hypothesis of the study is that the finishing treatments used had no effect on the color stability of the esthetic restorative materials tested.

\section{MATERIALS AND METHODS}

\section{Specimens' preparation}

The experimental design of the study is shown in Figure 1.

Esthetic restorative materials tested in this study are presented in Table 1. For each brand, the A2 Vita shade was selected.

\begin{tabular}{|c|c|c|c|}
\hline $\begin{array}{l}\text { Composites in } 7 \\
\text { levels ( } 40 \\
\text { samples for } \\
\text { each composite) }\end{array}$ & $\begin{array}{l}\text { Finishing/Polishing } \\
\text { procedures in } 4 \text { levels } \\
\text { (70 samples for each } \\
\text { group) }\end{array}$ & $\begin{array}{l}\text { Staining process } \\
\text { with coffee }\end{array}$ & $\begin{array}{l}\text { Time in } 5 \text { levels } \\
\text { (color evaluation } \\
\text { at } 0,7,14 \text { and } 28 \\
\text { days) }\end{array}$ \\
\hline \multicolumn{4}{|l|}{$\begin{array}{l}\text { Microfilled } \\
\text { composite } \\
\text { (Gradia Direct) }\end{array}$} \\
\hline $\begin{array}{l}\text { Nanofilled } \\
\text { composite } \\
\text { (Filtek Supreme } \\
\text { XTE) }\end{array}$ & $\begin{array}{l}\text { Group 1: control group } \\
\text { (no finishing/polishing } \\
\text { procedures) }\end{array}$ & $\begin{array}{l}\text { Immersion in } \\
\text { coffee (Nescafe } \\
\text { Classic) for } 28 \\
\text { days }\end{array}$ & $\begin{array}{l}\Delta \mathrm{E} \text { testing at } \mathrm{D0}, \\
\mathrm{D} 1, \mathrm{D} 2, \mathrm{D} 3, \mathrm{D} 4\end{array}$ \\
\hline $\begin{array}{l}\text { Nanoceramic } \\
\text { composite } \\
\text { (Ceram•X } \\
\text { Universal) }\end{array}$ & $\begin{array}{l}\text { Group 2: three polisher } \\
\text { interspersed with } \\
\text { diamond grit }\end{array}$ & $\begin{array}{l}\text { Immersion in } \\
\text { coffee (Nescafe } \\
\text { Classic) for } 28 \\
\text { days }\end{array}$ & $\begin{array}{l}\Delta \mathrm{E} \text { testing at } \mathrm{D} 0 \\
\mathrm{D} 1, \mathrm{D} 2, \mathrm{D} 3, \mathrm{D} 4\end{array}$ \\
\hline $\begin{array}{l}\text { Microfilled } \\
\text { hybrid } \\
\text { composite (G- } \\
\text { aenial) }\end{array}$ & $\begin{array}{l}\text { Group 3: two polisher } \\
\text { interspersed with } \\
\text { diamond grit }\end{array}$ & $\begin{array}{l}\text { Immersion in } \\
\text { coffee (Nescafe } \\
\text { Classic) for } 28 \\
\text { days }\end{array}$ & $\begin{array}{l}\Delta \mathrm{E} \text { testing at } \mathrm{D} 0 \\
\mathrm{D} 1, \mathrm{D} 2, \mathrm{D} 3, \mathrm{D} 4\end{array}$ \\
\hline $\begin{array}{l}\text { Microfilled } \\
\text { hybrid } \\
\text { composite } \\
\text { (Essentia) } \\
\text { Nanohybrid } \\
\text { Ormocer based } \\
\text { composite } \\
\text { (Admira Fusion) }\end{array}$ & $\begin{array}{l}\text { Group 4: one tungsten } \\
\text { carbide bur }+ \text { one } \\
\text { polisher interspersed } \\
\text { with diamond grit }\end{array}$ & $\begin{array}{l}\text { Immersion in } \\
\text { coffee (Nescafe } \\
\text { Classic) for } 28 \\
\text { days }\end{array}$ & $\begin{array}{l}\Delta \mathrm{E} \text { testing at } \mathrm{D} 0 \\
\mathrm{D} 1, \mathrm{D} 2, \mathrm{D} 3, \mathrm{D} 4\end{array}$ \\
\hline $\begin{array}{l}\text { Supra-nano } \\
\text { sphericalhybrid } \\
\text { composite } \\
\text { (Estelite) }\end{array}$ & & & \\
\hline
\end{tabular}

Figure 1: Flowchart of the experimentation 
Beltrami, et al.: Finishing/polishing procedures and discoloration of esthetic restorative materials

\begin{tabular}{|c|c|c|c|c|c|}
\hline Material & Type & Composition & $\begin{array}{c}\text { Filler content } \\
\text { percentage }(w / w)\end{array}$ & Manufacturer & Lot \# \\
\hline Gradia Direct & $\begin{array}{l}\text { Microfilled } \\
\text { composite }\end{array}$ & $\begin{array}{l}\text { Matrix: UDMA, dymethacrylate } \\
\text { camphoroquinone } \\
\text { Filler: Fluoro-alumino-silicate } \\
\text { glass silica powder }\end{array}$ & 73 & $\begin{array}{l}\text { GC Corporation, } \\
\text { Tokyo, Japan }\end{array}$ & $150527 \mathrm{~A}$ \\
\hline $\begin{array}{l}\text { Filtek supreme } \\
\text { XTE }\end{array}$ & $\begin{array}{l}\text { Nanofilled } \\
\text { composite }\end{array}$ & $\begin{array}{l}\text { Matrix: Bis-GMA, TEGDMA, } \\
\text { UDMA, Bis-EMA } \\
\text { Filler: Silica nanofillers }(5-75 \mathrm{~nm}) \text {, zirconia/ } \\
\text { silica nanoclusters }(0.6-1.4 \mu \mathrm{m})\end{array}$ & 78.5 & $\begin{array}{l}\text { 3M ESPE, St } \\
\text { Paul, MN, USA }\end{array}$ & N748173 \\
\hline $\begin{array}{l}\text { Ceram.X } \\
\text { Universal }\end{array}$ & $\begin{array}{l}\text { Nanoceramic } \\
\text { composite }\end{array}$ & $\begin{array}{l}\text { Matrix: Methacrylate modified ploysiloxane, } \\
\text { dimethacylate resin, fluorescent } \\
\text { pigment, UV stabilizer, stabilizer, } \\
\text { camphoroquinone, ethyl-4 (dymethylamino) } \\
\text { benzoate, iron oxide pigments, } \\
\text { aluminium sulfo silicate pigments } \\
\text { Filler: Barium-aluminium } \\
\text { borosilicate glass }(1.1-1.5 \mu \mathrm{m}), \\
\text { methacrylate functionalized silicon } \\
\text { dioxide nano filler }(10 \mathrm{~nm})\end{array}$ & 76 & $\begin{array}{l}\text { Dentsply De Trey, } \\
\text { Konstanz, Germany }\end{array}$ & 1507000661 \\
\hline G-Aenial & $\begin{array}{l}\text { Microfilled hybrid } \\
\text { composite }\end{array}$ & $\begin{array}{l}\text { Matrix: UDMA, dimethacrylate } \\
\text { co-monomers } \\
\text { Filler: Silica, strontium, lanthanoid } \\
\text { fluoride }(16-17 \mu \mathrm{m}), \text { silica }(>100 \\
\mathrm{nm}) \text { fumed silica }(<100 \mathrm{~nm})\end{array}$ & 76 & $\begin{array}{l}\text { GC Corporation, } \\
\text { Tokyo, Japan }\end{array}$ & $151029 \mathrm{~A}$ \\
\hline Essentia & $\begin{array}{l}\text { Microfilled hybrid } \\
\text { composite }\end{array}$ & $\begin{array}{l}\text { Matrix: UDMA, Bis-MEPP, } \\
\text { Bis-EMA, Bis-GMA, TEGDMA } \\
\text { Filler: Prepolymerised fillers, } \\
\text { barium glass, fumed silica }\end{array}$ & 81 & $\begin{array}{l}\text { GC Corporation, } \\
\text { Tokyo, Japan }\end{array}$ & $151109 \mathrm{C}$ \\
\hline Admira Fusion & $\begin{array}{l}\text { Nanohybrid } \\
\text { ormocer based } \\
\text { composite }\end{array}$ & $\begin{array}{l}\text { Matrix: Resine ormocer } \\
\text { Filler: Silicon oxide nanofiller, } \\
\text { glass ceramics filler }(1 \mu \mathrm{m})\end{array}$ & 84 & $\begin{array}{l}\text { Voco, Cuxhaven, } \\
\text { Germany }\end{array}$ & 1601121 \\
\hline Estelite & $\begin{array}{l}\text { Supra-nano } \\
\text { spherical hybrid } \\
\text { composite }\end{array}$ & $\begin{array}{l}\text { Matrix: Bis-GMA, Bis-MPEPP, TEGDMA, } \\
\text { UDMA } \\
\text { Filler: Supra-nano spherical filler ( } 200 \\
\text { nm spherical } \mathrm{SiO}_{2}-\mathrm{ZrO}_{2} \text { ), composite } \\
\text { filler (include } 200 \mathrm{~nm} \text { spherical } \mathrm{SiO}_{2}-\mathrm{ZrO} 2 \text { ) }\end{array}$ & 82 & $\begin{array}{l}\text { Tokuyama Dental } \\
\text { corporation, Taitou-ku, } \\
\text { Tokyo, Japan }\end{array}$ & $6,6 \mathrm{E}+17$ \\
\hline
\end{tabular}

All materials were polymerized according to the manufacturers' instructions into silicon rings (height $2 \mathrm{~mm}$; internal diameter $6 \mathrm{~mm}$; and external diameter $8 \mathrm{~mm}$ ) to obtain specimens identical in size. Cavities of these rings were slightly overfilled with material, covered with transparent polyester film strip (Mylar strip, Henry Schein, Melville, NY, USA), pressed between glass plates, and polymerized for 40 s on each side using a curing unit (Celalux II, Voco, Cuxhaven, Germany). One light polymerization mode was used for each material - standard: $1000 \mathrm{~mW} / \mathrm{cm}^{2}$ for $40 \mathrm{~s}$. The intensity of the light was verified with a radiometer (SDS Kerr, Orange, CA, USA). The light was placed perpendicular to the specimen surface at a distance of $1.5 \mathrm{~mm}$ to have the best intensity of light in accordance to the manufacturers' instructions.

\section{Finishing and polishing procedures}

The specimens were randomly assigned into four groups (10 specimens of each composite for each group). The upper surface of each specimen was finished/polished with different finishing/polishing procedures [Table 2].

- Group 1: Control group (no finishing/polishing procedures)

- Group 2: Three-polisher interspersed with diamond grit REF 4312A (9403 204 055, 9404204 055, and 9405204 055) (Komet, Gebr. Brasseler GmbH and Co., Germany)

- Group 3: Two-polisher interspersed with diamond grit REF 4652 (94025M 204070 and 94025F 204 070) (Komet, Gebr. Brasseler GmbH and Co., Germany)

- Group 4: One tungsten carbide bur + one polisher interspersed with diamond grit REF 4546 (H135Q 314 014, 9526UF 204 100) (Komet, Gebr. Brasseler $\mathrm{GmbH}$ and Co.).

To reduce variability, the same investigator performed all finishing/polishing procedures. The force used 
Beltrami, et al.: Finishing/polishing procedures and discoloration of esthetic restorative materials

\begin{tabular}{|c|c|c|c|c|}
\hline Groups & Manufacturers' code & Type & Abrasive & Manufacturer \\
\hline $\begin{array}{l}\text { Group } 1 \\
\text { (control) }\end{array}$ & No polishing/finishing & No polishing/finishing & $\begin{array}{l}\text { No polishing/ } \\
\text { finishing }\end{array}$ & None \\
\hline Group 2 & $\begin{array}{l}\text { REF 4312A: } 9403.204 .055 \\
9404.204 .055,9405.204 .055\end{array}$ & $\begin{array}{l}\text { Prepolishing } \\
\text { Polishing } \\
\text { High shine polishing }\end{array}$ & Diamond grit & $\begin{array}{l}\text { Komet, Gebr. Brasseler } \\
\text { GmbH and Co., Germany }\end{array}$ \\
\hline Group 3 & $\begin{array}{l}\text { REF 4546: H135Q.314.014, } \\
\text { 9526UF.204.100 }\end{array}$ & $\begin{array}{l}\text { Tungsten carbide bur } \\
\text { Polisher interspersed with diamonds grit }\end{array}$ & $\begin{array}{l}\text { Tungsten carbides } \\
\text { and diamond grit }\end{array}$ & $\begin{array}{l}\text { Komet, Gebr. Brasseler } \\
\text { GmbH and Co., Germany }\end{array}$ \\
\hline Group 4 & $\begin{array}{l}\text { REF 4652: } 94025 M .204 .070 \\
\text { 94025F.204.070 }\end{array}$ & $\begin{array}{l}\text { Polishing } \\
\text { High shine polishing }\end{array}$ & Diamond grit & $\begin{array}{l}\text { Komet, Gebr. Brasseler } \mathrm{GmbH} \text { and } \\
\text { Co., Germany }\end{array}$ \\
\hline
\end{tabular}

in the polishing procedure was controlled with a dynamometer (Taylor Dynamometer Inc., Milwaukee, WI, USA). The instruments were used parallel on the surface and each polisher was used for $10 \mathrm{~s}$.

\section{Staining process}

The staining solution used was coffee (Nescafe Classic, Nestle, Vevey, Switzerland). The coffee was prepared using a proportion of two spoons of powder for $250 \mathrm{ml}$ of water at room temperature. The specimens were immersed in staining solution at room temperature over a 28 -day test period. The control samples have not been subjected to the staining process and were stored in distilled water during the whole experimentation period. Staining solution was changed daily and put in vials with cover that prevent evaporation. Spectrophotometric analysis was made before staining, after staining, and after 7, 14, 21, and 28 days after the beginning of the experimentation. We indicate each time interval as D0, D1, D2, D3, and D4. Before each measurement, the specimens were rinsed with distilled water and air-dried.

\section{Color testing}

A blind trained operator performed the colorimetric evaluation according to the CIE L*a* $b^{*}$ system at six experimental periods: Immediately after light polymerization, after finishing/polishing procedures, and at $7,14,21$, and 28 days of the staining process. To simulate the absence of light in the mouth, the color of the specimens was measured against a black background with a spectrophotometer (SP820 $\lambda$; Techkon GmbH, Konig-Stein, Germany). All specimens were chromatically measured four times and the average values were calculated; then, each color parameter for each specimens of the same shade was averaged. The total color differences $\left(\Delta \mathrm{Eab}^{*}\right)$ were calculated as follows:

$\Delta \mathrm{E}_{\mathrm{ab}}{ }^{*}=\left[\left(\Delta \mathrm{L}^{*}\right)^{2}+\left(\Delta \mathrm{a}^{*}\right)^{2}+\left(\Delta \mathrm{b}^{*}\right)^{2}\right]^{1 / 2}$

Where $L^{*}$ is lightness, $a^{*}$ is green-red component $\left(-a^{*}=\right.$ green; $+a^{*}=$ red $)$, and $b^{*}$ is blue-yellow component $\left(-b^{*}=\right.$ blue; $+b^{*}=$ yellow $)$. A value of $\Delta \mathrm{Eab}^{*}<3.3$ was considered clinically acceptable in the present study. Color measurements of the experimental groups were compared with those of the control group.

\section{Statistical analysis}

Statistical analysis was performed using computer software (Stata 12.0, Stata Corp., Station College, TX, USA). Descriptive statistics including the mean, standard deviation, median, and minimum and maximum values were calculated for each color coordinate for all the groups. The distributions were assessed and found to be nonnormal (Shapiro-Wilk Test). Nonparametric Kruskal-Wallis one-way analysis of variance (ANOVA) by the factor of material was performed with the differences in color $\left(\Delta \mathrm{E}^{*} \mathrm{ab}\right)$ and three-color coordinates (CIE $\mathrm{L}^{*}$, CIE $\mathrm{a}^{*}$, and CIE $\mathrm{b}^{*}$ ) between different immersion protocols in the specimen conditions such as before staining and after staining at the significance level of 0.05 . Changes in color coordinates were calculated as "color coordinate of stained surfaces." Means of the different polishing/finishing groups were compared with Scheffe's multiple comparison test at the 0.05 level of significance.

\section{RESULTS}

The mean values and standard deviations of the color changes $(\Delta \mathrm{E})$ for each material are reported in Table 3. Every subsequent weekly measurement was collected to assess the color change in relation to the time of immersion. Thus, for each experimental group, every material has five mean values (D0, D1, D2, D3, and D4). Before immersion in staining solutions, the materials presented similar values $(P>0.05)$. According to ANOVA, the restorative material, time of exposure to the staining agent, and polishing/finishing technique were found statistically significance $(P<0.05)$ in color change. The absence of any polishing/finishing technique as control caused a significant lower 
Beltrami, et al.: Finishing/polishing procedures and discoloration of esthetic restorative materials

\begin{tabular}{|c|c|c|c|c|c|c|c|}
\hline & Gradia Direct & Filtek Supreme XTE & Ceram.X Universal & G-Aenial & Essentia & Admira Fusion & Estelite \\
\hline \multicolumn{8}{|c|}{ Group 1} \\
\hline D0 & $1.9^{\mathrm{A}}$ & $2.1^{\mathrm{A}}$ & $2.3^{\mathrm{A}}$ & $2.2^{\mathrm{A}}$ & $2.6^{\mathrm{A}}$ & $2.1^{\mathrm{A}}$ & $1.6^{\mathrm{A}}$ \\
\hline D1 & $4.2^{\mathrm{B}}$ & $5.2^{\mathrm{B}}$ & $3.3^{\mathrm{C}}$ & $4.2^{\mathrm{B}}$ & 5.8 & $2.6^{c}$ & $3.1^{\mathrm{c}}$ \\
\hline $\mathrm{D} 2$ & $10.1^{\mathrm{D}}$ & $12.1^{\mathrm{D}}$ & $5.2^{\mathrm{E}}$ & $6.7^{\mathrm{E}}$ & 8.3 & $4.4^{\mathrm{F}}$ & $4.7^{F}$ \\
\hline D3 & 13.5 & 20.2 & $10.1^{\mathrm{G}}$ & $10^{\mathrm{G}}$ & $10.1^{\mathrm{G}}$ & $6.9^{\mathrm{H}}$ & $6.3^{\mathrm{H}}$ \\
\hline D4 & 17.4 & 24.4 & $14.8^{1}$ & $15.1^{\prime}$ & 11.4 & 9.9 & 7.7 \\
\hline \multicolumn{8}{|c|}{ Group 2} \\
\hline Do & $0.4^{\mathrm{A}}$ & $0.6^{\mathrm{A}}$ & $0.8^{\mathrm{A}}$ & $0.7^{\mathrm{A}}$ & $1.1^{\mathrm{A}}$ & $0.6^{\mathrm{A}}$ & $0.1^{\mathrm{A}}$ \\
\hline D1 & $0.9^{\mathrm{B}}$ & $2.4^{\mathrm{C}}$ & $2.5^{\mathrm{C}}$ & $3.7^{\mathrm{D}}$ & $3.8^{\mathrm{D}}$ & $4^{\mathrm{D}}$ & $1.3^{\mathrm{B}}$ \\
\hline D2 & $4.4^{\mathrm{E}}$ & $3^{F}$ & $4^{\mathrm{E}}$ & $4.9^{\mathrm{E}}$ & $9.8^{\mathrm{G}}$ & $11^{\mathrm{G}}$ & $2.3^{F}$ \\
\hline D3 & $11.5^{\mathrm{H}}$ & $6^{1}$ & $5.5^{1}$ & $6^{\prime}$ & $11.8^{\mathrm{H}}$ & $12.6^{\mathrm{H}}$ & $6.8^{1}$ \\
\hline D4 & 19.6 & $7^{\llcorner}$ & $7^{\llcorner}$ & $7.5^{\llcorner}$ & 13.2 & 16 & 10.8 \\
\hline \multicolumn{8}{|c|}{ Group 3} \\
\hline D0 & $0.6^{A}$ & $0.8^{\mathrm{A}}$ & $1^{\mathrm{A}}$ & $0.9^{A}$ & $1.3^{\mathrm{A}}$ & $0.8^{A}$ & $0.3^{\mathrm{A}}$ \\
\hline D1 & $3.5^{\mathrm{B}}$ & 6.3 & $3.7^{\mathrm{B}}$ & 4.9 & 8.3 & $2.3^{c}$ & $2.3^{c}$ \\
\hline D2 & $6.4^{\mathrm{D}}$ & $8^{\mathrm{E}}$ & $5.7^{\mathrm{D}}$ & $8.4^{\mathrm{E}}$ & 13.5 & $5.8^{\mathrm{D}}$ & 3.7 \\
\hline D3 & $9.9^{F}$ & $10^{\mathrm{F}}$ & $6.9^{\mathrm{G}}$ & 12.4 & 20.5 & $7^{G}$ & $6.7^{\mathrm{G}}$ \\
\hline D4 & $12.9^{\mathrm{H}}$ & $13.6^{\mathrm{H}}$ & 9.7 & 14.8 & 27.5 & $13.5^{\mathrm{H}}$ & 7.6 \\
\hline \multicolumn{8}{|c|}{ Group 4} \\
\hline D0 & $0.3^{\mathrm{A}}$ & $0.5^{\mathrm{A}}$ & $0.7^{\mathrm{A}}$ & $0.6^{\mathrm{A}}$ & $1^{\mathrm{A}}$ & $0.5^{\mathrm{A}}$ & $0.1^{\mathrm{A}}$ \\
\hline D1 & $2.8^{\mathrm{B}}$ & 5.7 & $2.9^{B}$ & $2.2^{\mathrm{B}}$ & 8 & $3.2^{\mathrm{B}}$ & $1.6^{\mathrm{B}}$ \\
\hline D2 & $5^{c}$ & $7.2^{\mathrm{D}}$ & $7.9^{\mathrm{D}}$ & $5.5^{\mathrm{C}}$ & 11.1 & $6.9^{D}$ & $5^{c}$ \\
\hline D3 & $9.7^{\mathrm{E}}$ & $10.3^{\mathrm{E}}$ & $10.4^{\mathrm{E}}$ & 7.2 & 17.2 & 14 & $11^{\mathrm{E}}$ \\
\hline D4 & 14.2 & $16.9^{F}$ & $12.6^{G}$ & 10.2 & 21.4 & $16.5^{\mathrm{F}}$ & $12.5^{\mathrm{G}}$ \\
\hline
\end{tabular}

Same superscript letters indicate no significant differences in row $(P>0.05)$. D0, D1, D2, D3, and D4 indicate time intervals between each spectrophotometric measurement. In row, if significance indicator is missing, there are significant differences among restorative materials

staining for Essentia, Admira Fusion, and Estelite if compared to the other restorative materials that significantly changed their colorimetric parameters in 4 weeks $(P>0.05)$ [Figure 2]. The polishing/finishing technique used in Group2 (three polishers interspersed with diamond grit) caused a significantly different color change for all the materials tested if compared to control group. Filtek Supreme XTE, G-aenial, and Ceram.X Universal showed a significantly lower degree of staining than in Group $1(P<0.05)$. The other restorative materials showed significantly higher values than in Group 1 with the main increase between the $1^{\text {st }}$ and the $3^{\text {rd }}$ week [Figure 3]. Data deriving from samples in Groups 3 and 4 showed similar staining degree of the restorative materials [Figures 4 and 5], except for Essentia which registered the highest discoloration in time $(P<0.05)$. The polishing/finishing technique used for Group 3 tended to maintain lower staining when compared with Group 4, except for Essentia.

\section{DISCUSSION}

The null hypothesis of the study that the finishing treatments used had no effect on the color stability of the esthetic restorative materials tested was rejected.

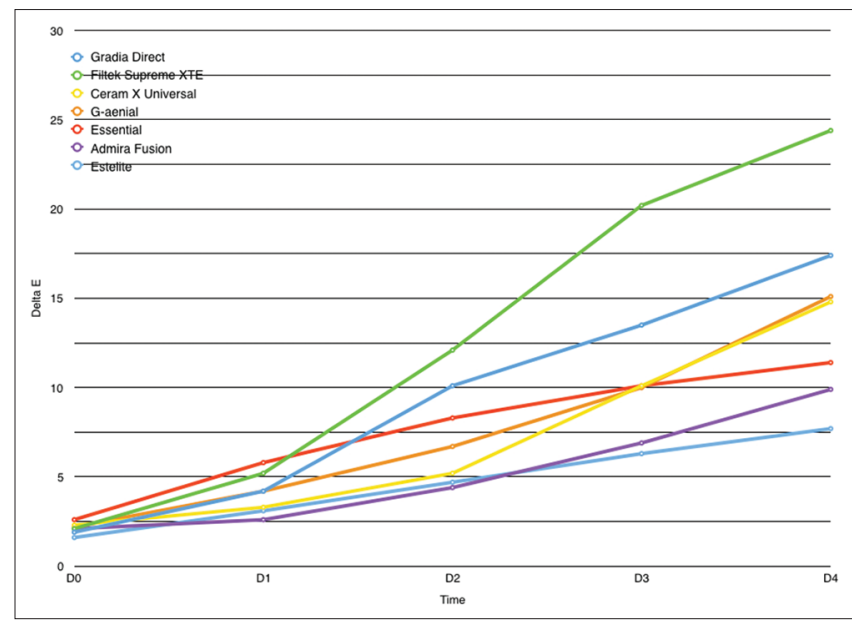

Figure 2: Color change values for the esthetic restorative materials tested reported at D0, D1, D2, D3, and D4 for Group 1

In fact, not only the time of exposure to the staining agent but also the polishing/finishing technique played a significant role in color change. Visually and/or specific instruments can be used to assess color change of dental materials. ${ }^{[11]}$ Various studies reported the advantages of using the CIE L*a*b* coordinate system, such as its repeatability, sensitivity, and objectivity. This technique was chosen to evaluate the color variation $(\Delta \mathrm{E})$ because it is well suited 


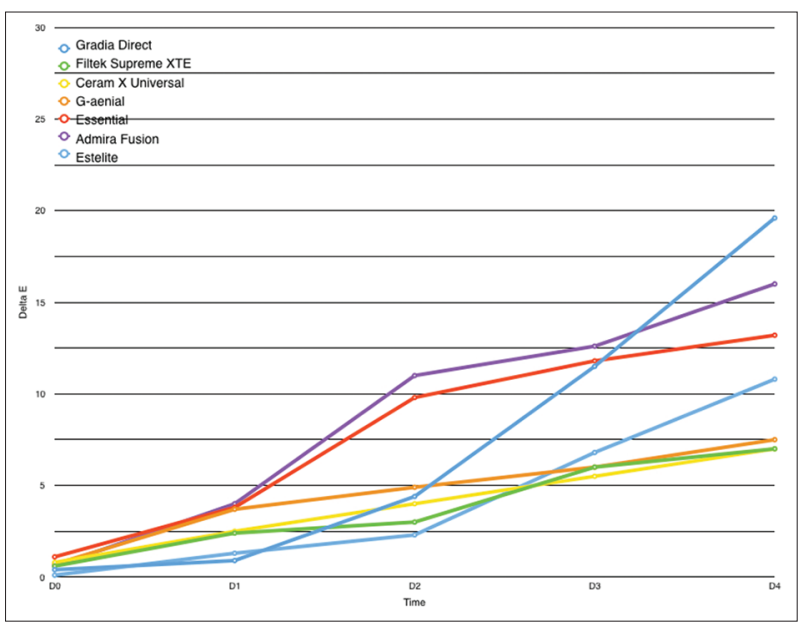

Figure 3: Color change values for the esthetic restorative materials tested reported at D0, D1, D2, D3, and D4 for Group 2

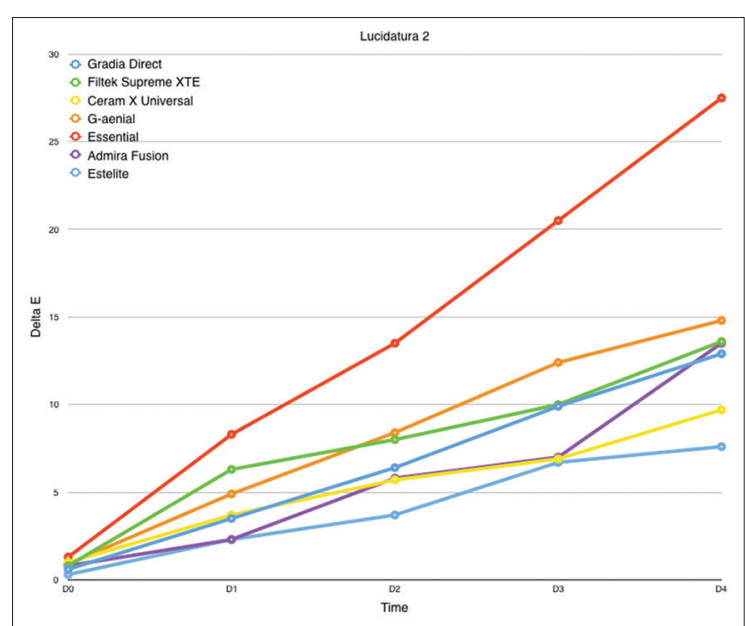

Figure 4: Color change values for the esthetic restorative materials tested reported at D0, D1, D2, D3, and D4 for Group 3

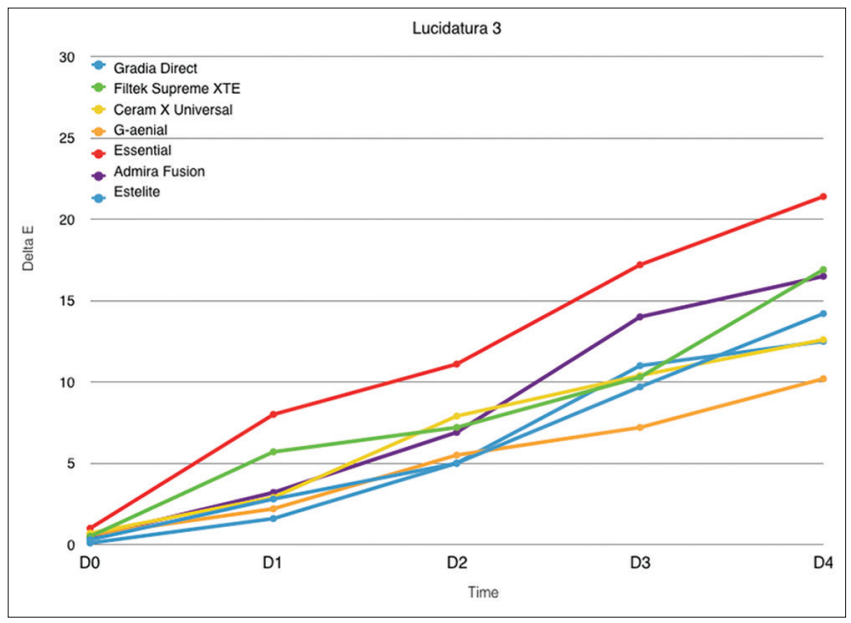

Figure 5: Color change values for the esthetic restorative materials tested reported at D0, D1, D2, D3, and D4 for Group 4

for the determination of small color variations. ${ }^{[13]}$ Several authors have reported that $\Delta \mathrm{E}$ values ranging from 1 to 3 are perceptible to the naked eye and $\Delta \mathrm{E}$ values $>3.3$ are clinically unacceptable. ${ }^{[13,14]}$ In this study, almost all the materials tested presented an unacceptable color variation $(\Delta \mathrm{E} \geq 3.3)$ after 1 week of the staining process regardless of the finishing treatment performed.

According to Ertaş et al., ${ }^{[15]}$ in this study, a long-term staining protocol of 28 days was performed. This time of exposure should simulate around 2 years of clinical exposure to the staining agents $(24 \mathrm{~h}$ in vitro corresponds to about 1 month in vivo), which is considered sufficient for long-term staining susceptibility evaluation.

Coffee was selected as the staining agents, in accordance with the studies which demonstrated that certain substances (e.g., coffee) may cause more severe staining than other. ${ }^{[16]}$

The effectiveness of finishing/polishing procedures on composite surface is an important goal to be achieved in the restorative process; resin composite restoration can be imperceptible only if its surface closely resembles the enamel surface. It is well known that the smoothest obtainable surface is achieved by curing the material in direct contact with a Mylar strip. ${ }^{[17]}$ For recontouring restorations or removing excess material, some abrasive instruments such as flexible discs and finishing burs are used. Numerous studies indicate that rubber polishers with diamond grit produce smoother surfaces than diamond finishing burs, tungsten carbide burs, or mounted stones. ${ }^{[3,18]}$ Similarly, in this study (except for Essentia), the finishing technique used for Groups 2 and 3 (polishers alone) tended to maintain lower staining when compared with Group 4 (tungsten carbide bur + polisher). Hence, we can say that rubber polishers created smoother surfaces and therefore lower staining susceptibility if compared to the use of carbide burs.

According to Paravina et al., ${ }^{[5]}$ a decrease in the particle size of the abrasive produces a superior surface. The grit in the polishing material should be smaller than the particle size of the restorative material that is being polished to produce better results. A recent study showed that polishers' capability of producing smooth surfaces was related to their ability to cut the filler particle and matrix equally. ${ }^{[19]}$ In the present study, carbide burs produced higher color variations than the other groups. These instruments are necessary for contouring anatomically structured and concave 
surfaces such as the lingual surface of anterior teeth or the occlusal surfaces of posterior teeth. ${ }^{[3]}$ Furthermore, while diamond burs were best suited for gross removal and contouring because of their high cutting efficiency, carbide burs would be best suited for smoothing and finishing because of their low cutting efficiency. However, various studies are in accordance with the findings of this study, underlying that finishing carbide produce rough surfaces and therefore higher discoloration compared with those produced by rubber polishers or aluminum discs. ${ }^{[20]}$

As regards the type of composite resin, in this study, in the absence of any finishing treatment (control group), the lower staining was recorded for the hybrid composites (Essentia, Admira Fusion, and Estelite) if compared to the other restorative materials. Without finishing procedure, these three different hybrid composites demonstrated lower staining susceptibility if compared to the other microfilled and nanofilled materials tested. Similar results were reported in our previous study, in which Estelite and Admira Fusion showed similar results, thus demonstrating the lowest $\Delta \mathrm{E} \cdot{ }^{[21]}$ Our results are also in accordance with recent studies which reported higher discoloration for nanofilled composites compared to nanohybrid ones. ${ }^{[22,23]}$ Ayad showed for Ormocer composites significantly lower color susceptibility if compared to nanofilled resins. ${ }^{[24]}$

However, in this study, after the polishing/finishing protocols, the behavior of the materials tested changed. Finishing caused a significantly different color change for all the materials tested if compared to control group and the nanofilled composites Filtek Supreme XTE and Ceram.X Universal showed a significantly lower degree of staining. After finishing, the other restorative materials showed significantly higher values and particularly the microhybrid composite Essentia reported the highest values of discoloration after all the three different finishing protocols. This finding can be explained by the polishability of the resin composite, which is directly affected by the filler particle size. Generally, the smaller the average particle size, the easier it will be to polish the resin. ${ }^{[25]}$ The filler content of the composite affects its roughness; consequently, nanofilled composites showed smoother surfaces than microfilled composites. ${ }^{[26]}$ In addition to this, in the present study, polished nanofilled composites showed lower discoloration (and probably lower surface roughness) if compared to polished hybrid resins. As it was stated before, nanofilled composite resins contain fillers with size ranging from around 5 to $100 \mathrm{~nm}$, and the particle size is similar. ${ }^{[10]}$ However, hybrid composite resins contain fillers with different particle sizes. The finishing burs or the polisher cut better particles with similar size while the presence of inhomogeneous fillers (as for hybrid composites) reduce the effect of polishing of the instrument used. For this reason, after the finishing procedures, the nanofilled composite resin tested in this study showed lower discoloration than hybrid composite resin materials.

\section{CONCLUSIONS}

Within the limitations of this study, the finishing treatments used had a significant effect on the color stability of the esthetic restorative materials tested. The time of exposure to the staining agent and the polishing/finishing technique influenced the color change.

\section{Financial support and sponsorship}

Nil.

\section{Conflicts of interest}

There are no conflicts of interest.

\section{REFERENCES}

1. Aytac F, Karaarslan ES, Agaccioglu M, Tastan E, Buldur M, Kuyucu E. Effects of novel finishing and polishing systems on surface roughness and morphology of nanocomposites. J Esthet Restor Dent 2016;28:247-61.

2. Rai R, Gupta R. In vitro evaluation of the effect of two finishing and polishing systems on four esthetic restorative materials. J Conserv Dent 2013;16:564-7.

3. Kumari RV, Nagaraj H, Siddaraju K, Poluri RK. Evaluation of the effect of surface polishing, oral beverages and food colorants on color stability and surface roughness of nanocomposite resins. J Int Oral Health 2015;7:63-70.

4. Yildiz E, Sirin Karaarslan E, Simsek M, Ozsevik AS, Usumez A. Color stability and surface roughness of polished anterior restorative materials. Dent Mater J 2015;34:629-39.

5. Paravina RD, Roeder L, Lu H, Vogel K, Powers JM. Effect of finishing and polishing procedures on surface roughness, gloss and color of resin-based composites. Am J Dent 2004;17:262-6.

6. Koc-Vural U, Baltacioglu I, Altinci P. Color stability of bulk-fill and incremental-fill resin-based composites polished with aluminum-oxide impregnated disks. Restor Dent Endod 2017;42:118-24.

7. Yap AU, Ng JJ, Yap SH, Teo CK. Surface finish of resin-modified and highly viscous glass ionomer cements produced by new one-step systems. Oper Dent 2004;29:87-91.

8. Filho HN, D'Azevedo MT, Nagem HD, Marsola FP. Surface roughness of composite resins after finishing and polishing. Braz Dent J 2009;14:37-41.

9. Villalta P, Lu H, Okte Z, Garcia-Godoy F, Powers JM. Effects of staining and bleaching on color change of dental composite resins. J Prosthet Dent 2006;95:137-42.

10. Soares-Geraldo D, Scaramucci T, Steagall W Jr., Braga SR, Sobral MA Interaction between staining and degradation of a composite resin in contact with colored foods. Braz Oral Res 2011;25:369-75.

11. Borges A, Caneppele T, Luz M, Pucci C, Torres C. Color stability of resin used for caries infiltration after exposure to different staining solutions. Oper Dent 2014;39:433-40. 
12. Schulze KA, Marshall SJ, Gansky SA, Marshall GW. Color stability and hardness in dental composites after accelerated aging. Dent Mater 2003;19:612-9.

13. Poggio C, Beltrami R, Scribante A, Colombo M, Chiesa M. Surface discoloration of composite resins: Effects of staining and bleaching. Dent Res J (Isfahan) 2012;9:567-73.

14. Brook AH, Smith RN, Lath DJ. The clinical measurement of tooth colour and stain. Int Dent J 2007;57:324-30.

15. Ertaş E, Güler AU, Yücel AC, Köprülü H, Güler E. Color stability of resin composites after immersion in different drinks. Dent Mater J 2006;25:371-6.

16. Mundim FM, Garcia Lda F, Pires-de-Souza Fde C. Effect of staining solutions and repolishing on color stability of direct composites. J Appl Oral Sci 2010;18:249-54.

17. Roeder LB, Powers JM. Surface roughness of resin composite prepared by single-use and multi-use diamonds. Am J Dent 2004;17:109-12.

18. Ferraris F, Conti A. Superficial roughness on composite surface, composite enamel and composite dentin junctions after different finishing and polishing procedures. Part I: Roughness after treatments with tungsten carbide vs. Diamond burs. Int J Esthet Dent 2014;9:70-89.

19. Kumari CM, Bhat KM, Bansal R. Evaluation of surface roughness of different restorative composites after polishing using atomic force microscopy. J Conserv Dent 2016;19:56-62.

20. Gönülol N, Yilmaz F. The effects of finishing and polishing techniques on surface roughness and color stability of nanocomposites. J Dent 2012;40 Suppl 2:e64-70.

21. Ceci M, Viola M, Rattalino D, Beltrami R, Colombo M, Poggio C, et al. Discoloration of different esthetic restorative materials: A spectrophotometric evaluation. Eur J Dent 2017;11:149-56.

22. Farah RI, Elwi H. Spectrophotometric evaluation of color changes of bleach-shade resin-based composites after staining and bleaching. J Contemp Dent Pract 2014;15:587-94.

23. Malhotra N, Shenoy RP, Acharya S, Shenoy R, Mayya S. Effect of three indigenous food stains on resin-based, microhybrid and nanocomposites. J Esthet Restor Dent 2011;23:250-7.

24. Ayad NM. Susceptibility of restorative materials to staining by common beverages: An in vitro study. Eur J Esthet Dent 2007;2:236-47.

25. Avsar A, Yuzbasioglu E, Sarac D. The effect of finishing and polishing techniques on the surface roughness and the color of nanocomposite resin restorative materials. Adv Clin Exp Med 2015;24:881-90.

26. Yadav RD, Raisingani D, Jindal D, Mathur R. A comparative analysis of different finishing and polishing devices on nanofilled, microfilled, and hybrid composite: A Scanning electron microscopy and profilometric study. Int J Clin Pediatr Dent 2016;9:201-8. 